\title{
AOR
}

Selected Papers of \#AolR2021:

The 22nd Annual Conference of the Association of Internet Researchers Virtual Event / 13-16 Oct 2021

\section{PUBLIC POLICY MEETS PUBLIC SURVEILLANCE}

Sharon Strover

University of Texas at Austin

Tiancheng Cao

University of Texas at Austin

Maria Esteva

University of Texas at Austin

Soyoung Park

University of Texas at Austin

\section{Introduction}

Deploying municipal camera systems has catalyzed several debates and even violent reactions in major cities around the world. This has everything to do with the increasingly advantageous capabilities of these cameras and other 'smart city' technologies, including Al-enhanced data collection and analytics possibilities associated with the Internet of Things (D'Ignazio \& Klein, 2020; Buccelatto, 2020; Shaffer, 2021). These cameras promise functionality and cost savings for municipalities, but also surveillance opportunities for government authorities. In Hong Kong, for example, smart streetlights have been attacked out of concern over their surveillance capabilities; in the US, when publics become aware of these systems, concern and outrage sometimes have erupted. In the US, only a few cities have policies regarding these technologies (Chivukula \& Takemoto, 2021). Matters of citizen independence and algorithmic bias lack robust discussion in many smart cities initiatives.

\section{Research approach}

To investigate the theoretical and political implications of city-deployed camera systems, we examine infrastructure adoption and public engagement practices in seven US cities exercising varied approaches. While this design sacrifices the insights available from other countries' experiences, it provides a culturally and legislatively cohesive set of cases. Our research is multi-site and multi-method, combining case studies with results from a Delphi survey of US experts with 'smart cities' experience. 
Our cases examine decision-making and public policies associated with public cameras. Analytic categories include governance, infrastructure choices, data policies, public engagement, and oversight mechanisms.

We investigated deployments in: Chicago, with its NSF-funded 'Array of Things'; Denver, which expanded camera networks using existing public infrastructure; Detroit, with its 'Project Green Light' mobilizing voluntary business participation; Portland, Oregon, which banned the use of facial recognition technologies (FRT); San Diego, using smart streetlights; San Francisco, with a privately-funded and neighborhood-run camera network monitoring neighborhood safety; and Seattle, which implemented public engagement processes for its Surveillance Ordinance. Summary results are presented in Table 1.

\section{Governance}

The seven cities exhibit varying levels of public involvement, from city-led efforts (Denver, San Diego, Seattle), to forms of public-private-partnerships (PPP) (Chicago, Detroit, Portland), to a privately funded project operated by neighborhood coalitions (San Francisco). Governance structures are closely related to the projects' intended goals. When led by local police departments, they prioritize policing and surveillance over environmental and transportation concerns and community buy-in. In San Diego, smart streetlights intended for energy-saving and traffic improvements were turned into a police surveillance tool without the knowledge of city council or the public (Marx, 2020). Local debates regarding privacy, transparency, and fairness occurred in Seattle, San Diego, Detroit, and San Francisco (Harmon, 2019; Bowles, 2020).

\section{Infrastructure}

The projects' infrastructural components, both hardware and software, come primarily from the commercial sector. In Chicago, the exception, an open-source platform was developed by researchers from University of Chicago and Argonne National Laboratory. In all other cities, infrastructure and technology support are provided by private-sector vendors such as GE and Applied Video Solutions. For example, Portland's Smart City PDX initiative utilizes both the system from Chicago and the same sensor nodes (developed by GE) used in San Diego.

CCTV cameras and environmental sensors are the most common types of hardware. However, some cities may not utilize equipment functions to the fullest extent. Portland, for instance, has turned off the microphones on its sensors and does not save raw video footage (The City of Portland, 2018). By contrast, San Diego uses microphones and saves raw footage for up to five days (The City of San Diego, 2019). Detroit embraces automated facial recognition but claims it is not used in real-time monitoring. Denver, San Diego, and San Francisco all claim to have no built-in FRT functionalities; Portland and Seattle prohibit the use of FRT by most public offices, with Portland extending the ban to private entities in public spaces (Becker, 2020).

\section{Data}


Most city-sponsored projects in our study lack explicitly stated data policies regarding public surveillance projects. Portland and San Diego only reference the city's open data policy, and while Portland has an Open Data policy it does not specifically mention video data. Chicago's data collection and dissemination process is detailed in a scientific journal; Seattle's 2018 Surveillance Impact Report explicitly outlines the collection, use, storage, deletion, and sharing of data associated with the use of CCTV cameras (Seattle Department of Transportation, 2019). A San Francisco lawsuit alleges that local police used private camera data during Black Lives Matter protests, violating the city's Surveillance Technology Ordinance (San Francisco Ordinance 107-19).

\section{Public engagement}

Both Denver and San Diego have been criticized for their 'secret' deployment or expansion of surveillance networks, highlighting the lack of public communication and community outreach. In Detroit and Portland, public feedback was gathered for earlystage pilot programs, but the Detroit system remains contested by public groups such as Detroit Community Technology. In San Francisco, neighborhood coalitions run and establish policy on localized camera systems. Chicago adopts a more proactive approach to public engagement, partnering with local civic groups, obtaining community feedback, publishing engagement reports, and creating educational outreach in local schools (Thornton, 2018); Seattle is the only city in our study that formalizes public engagement procedures in its surveillance ordinance (Young et al., 2019).

\section{Oversight}

Similar to data policies, many cities do not have well-established oversight mechanisms. Chicago, Portland, and Seattle have an internal work group or committee responsible for project review and assessment. Portland, San Diego, San Francisco and Seattle recently passed ordinances that govern the procurement and use of public surveillance technologies, although San Diego did so only after local news revealed the clandestine operations of the local police department (Marx, 2020). Litigation is underway in San Francisco regarding police use of privately generated video data. 
Table 1: Cities by Factors in Municipal Camera Programs

\begin{tabular}{|c|c|c|c|c|c|c|c|}
\hline \multirow{2}{*}{$\frac{3}{0}$} & \multicolumn{2}{|c|}{ Governance } & \multicolumn{2}{|c|}{ Infrastructure } & \multirow{2}{*}{ Data } & \multirow{2}{*}{ Public Engagement } & \multirow{2}{*}{ Oversight } \\
\hline & Goal & Structure & Supplier & Capabilities & & & \\
\hline 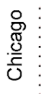 & $\begin{array}{l}\text { environment, } \\
\text { transportation }\end{array}$ & PPP & $\begin{array}{l}\text { university and } \\
\text { national lab }\end{array}$ & sensors, cameras & $\begin{array}{l}\text { open, free public access } \\
\text { to aggregate data }\end{array}$ & $\begin{array}{l}\text { partner with civic groups, } \\
\text { invite community feedback, } \\
\text { publish engagement report, } \\
\text { education outreach }\end{array}$ & $\begin{array}{l}\text { internal working group, } \\
\text { independent reviewing } \\
\text { committee }\end{array}$ \\
\hline 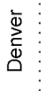 & policing & public & $\begin{array}{l}\text { expand by } \\
\text { accessing } \\
\text { existing } \\
\text { networks }\end{array}$ & $\begin{array}{c}\text { real-time monitoring and } \\
\text { tracking, shot-spotting } \\
\text { computer-aided dispatch; } \\
\text { no FRT }\end{array}$ & $\begin{array}{l}\text { only available to law } \\
\text { enforcement }\end{array}$ & none specified & $\begin{array}{l}\text { police claims system in line } \\
\text { with city's Strategic Plan } \\
2019-2023\end{array}$ \\
\hline : & policing & PPP & private vendors & $\begin{array}{l}\text { real-time monitoring, } \\
\text { built-in FRT, indoor' } \\
\text { cameras, a 'priority' } \\
\text { response system }\end{array}$ & $\begin{array}{l}\text { only available to law } \\
\text { enforcement }\end{array}$ & $\begin{array}{l}\text { pilot programs for awareness } \\
\text { building, public safety } \\
\text { meetings by police }\end{array}$ & $\begin{array}{l}\text { MOU to be renewed in } \\
\text { annual meetings; city council } \\
\text { proposed governing } \\
\text { ordinance in April } 2021\end{array}$ \\
\hline $\begin{array}{l}\frac{\overline{0}}{\mathrm{~T}} \\
\frac{\mathrm{T}}{\mathrm{t}} \\
\frac{\mathrm{t}}{0}\end{array}$ & $\begin{array}{l}\text { environment, } \\
\text { transportation }\end{array}$ & PPP & private vendors & $\begin{array}{c}\text { sensors, cameras } \\
\text { (microphones turned off); } \\
\text { bans FRT }\end{array}$ & $\begin{array}{c}\text { only saves aggregated } \\
\text { data }\end{array}$ & $\begin{array}{l}\text { consultations with targeted } \\
\text { communities, early-stage } \\
\text { public comments }\end{array}$ & $\begin{array}{l}\text { city ordinances, privacy work } \\
\text { group }\end{array}$ \\
\hline 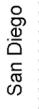 & $\begin{array}{l}\text { policing (originally: } \\
\text { energy-saving, } \\
\text { environment, } \\
\text { transportation) }\end{array}$ & public & private vendors & $\begin{array}{l}\text { sensors, cameras; no } \\
\text { FRT }\end{array}$ & $\begin{array}{c}\text { raw footage stored for } \\
\text { five days; free public } \\
\text { access to aggregate } \\
\text { data }\end{array}$ & $\begin{array}{c}\text { community forums and tours, } \\
\text { community advocacy } \\
\text { coalition as engagement } \\
\text { broker }\end{array}$ & $\begin{array}{l}\text { no prior mechanism, city } \\
\text { council passes two } \\
\text { ordinances after the fact }\end{array}$ \\
\hline 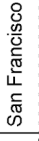 & $\begin{array}{l}\text { community } \\
\text { surveillance }\end{array}$ & private & $\begin{array}{l}\text { one private } \\
\text { donor }(\$ 4 \\
\text { million in } \\
\text { cameras) }\end{array}$ & $\begin{array}{l}\text { higher image quality, } \\
\text { large field of vision, } \\
\text { close-up monitoring; no } \\
\text { FRT }\end{array}$ & $\begin{array}{c}\text { footage and analytics } \\
\text { managed by } \\
\text { neighborhood coalition }\end{array}$ & $\begin{array}{l}\text { decision making by } \\
\text { neighborhood coalition }\end{array}$ & $\begin{array}{l}\text { authorized by neighborhood } \\
\text { association }\end{array}$ \\
\hline 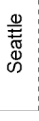 & $\begin{array}{l}\text { policing, utility, fire, } \\
\text { transportation }\end{array}$ & public & private vendors & $\begin{array}{l}\text { cameras, automated } \\
\text { license plate recognition, } \\
\text { Booking Photo } \\
\text { Comparison }\end{array}$ & $\begin{array}{l}\text { comprehensive data } \\
\text { policies in Surveillance } \\
\text { Impact Report }\end{array}$ & $\begin{array}{l}\text { public presentations, } \\
\text { structured discussions, } \\
\text { public comment period }\end{array}$ & $\begin{array}{l}\text { community surveillance } \\
\text { working group performs } \\
\text { annual privacy and civil } \\
\text { liberties impact assessment }\end{array}$ \\
\hline
\end{tabular}

\section{References}

Becker, T. (2020, September 9). City Council approves ordinances banning use of face recognition technologies by City of Portland bureaus and by private entities in public spaces. Portland.Gov. https://www.portland.gov/smart-citypdx/news/2020/9/9/city-council-approves-ordinances-banning-use-facerecognition

Bowles, N. (2020, July 10). Why is a tech executive installing security cameras around San Francisco? The New York Times. https://www.nytimes.com/2020/07/10/business/camera-surveillance-sanfrancisco.html

Buccelatto, P. (Jan 9, 2020). How cities can turn CCTV into smart sensors. Government Technology. https://www.govtech.com/opinion/How-Cities-CanTurn-CCTV-into-Smart-Sensors-Contributed.html

Chivukula, A., and Takemoto, T. (2021, February). Local surveillance oversight ordinances. Samuelson Clinic Student White Paper. https://www.law.berkeley.edu/wp-content/uploads/2021/02/Local-SurveillanceOrdinances-White-Paper.pdf 
D’Ignazio, C., \& Klein, L. F. (2020). Data feminism. The MIT Press.

Harmon, A. (2019, July 8). As Cameras Track Detroit's Residents, a Debate Ensues Over Racial Bias (Published 2019). The New York Times. https://www.nytimes.com/2019/07/08/us/detroit-facial-recognition-cameras.html

Marx, J. (2020, July 20). Smart streetlights are now exclusively a tool for police. Voice of San Diego. https://www.voiceofsandiego.org/topics/public-safety/smartstreetlights-are-now-exclusively-a-tool-for-policel

San Francisco Administrative Code-Acquisition of Surveillance Technology. Ordinance No .107-19, Chapter 19B.

Shaffer, G. (2021, February). Applying a contextual integrity framework to privacy policies for smart technologies. TPRC48 Conference. https://ssrn.com/abstract $=3742916$

Seattle Department of Transportation. (2019). 2018 Surveillance Impact Report: Closed Circuit Television "Traffic Cameras." http://www.seattle.gov/Documents/Departments/Tech/2018-1008\%20DRAFT\%20SIR\%20-\%20CCTV\%20Traffic\%20Cameras\%20\%20For\%20Public\%20Comment.pdf

The City of Portland. (2018). How Privacy is Protected. The City of Portland, Oregon. https://www.portlandoregon.gov/transportation/76740

The City of San Diego. (2019). Smart Streetlights City of San Diego Public Meeting. https://www.sandiego.gov/sites/default/files/sust-smartstreetlightpublicmeeting$\underline{091019 . p d f}$

Thornton, S. (2018, January 2). A guide to Chicago's Array of Things initiative. DataSmart City Solutions. https://datasmart.ash.harvard.edu/news/article/a-guide-tochicagos-array-of-things-initiative-1190

Young, M., Katell, M., \& Krafft, P. M. (2019). Municipal surveillance regulation and algorithmic accountability. Big Data \& Society, 6(2), 2053951719868492. https://doi.org/10.1177/2053951719868492 